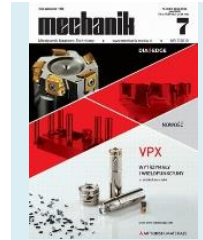

Author: Andrzej Zaborski

Title of article: „Przygotowanie produkcji z zastosowaniem systemów CAD i CAD/CAM” (“Manufacturing preparation using CAD and CAD/CAM software")

Mechanik, Vol. 91, No. 7 (2018): pages 567-569

DOI: https://doi.org/10.17814/mechanik.2018.7.86

\title{
Manufacturing preparation using CAD and CAD/CAM software
}

\author{
Przygotowanie produkcji z zastosowaniem \\ systemów CAD i CAD/CAM
}

ANDRZEJ ZABORSKI *

A possibility of using contemporary CAD and CAD/CAM systems for computer-integrated developing the processes of preparation products manufacturing is presented. On the example of the modernization of the lock lever of the head of the sewing machine in article discussed design process and production preparation using numerically controlled machines.

KEYWORDS: computer-aided production preparation, CAD and CAD/CAM systems

The use of computer systems of the CAD and CAD/CAM type for the implementation of the design and construction process allowed the introduction of profound changes at all stages of product preparation [5, 6]: starting with the appearance of the product concept, through the stage of initial calculations, selection of the variant the final construction solution, preparing the documentation, and ending with the generation of the machine control code [24].

The starting point for all kinds of work related to the computer-aided preparation of the implementation process for the production of a new or modernized product must become the design of components from which the designed object is created (initially virtually). This is usually done in specialized CAD programs or design modules of integrated $\mathrm{CAD} / \mathrm{CAM} / \mathrm{CAE}$ production preparation systems.

Computer analysis of the functioning of designed solutions allows to estimate the loads and excitations affecting individual elements of the designed devices. It becomes possible to analyze the state of stresses and strains using, for example, the finite element method.

The next stage of production preparation is the use of CAD/CAM systems (or modules) for the technological preparation of the production process (including the choice of the machine tool, preparation of individual machining operations, selection of tools and machining parameters).

The final stage of the work carried out in the CAD/CAM system is usually the execution of a machining process simulation allowing for the correction of possible mistakes and the generation and derivation of the control code into a numerically controlled machine tool.

\footnotetext{
* Dr hab. inż. Andrzej Zaborski prof. PCz (zaborski@itm.pcz.czest.pl) Instytut Technologii Mechanicznych Politechniki Częstochowskiej
}

An example of such an approach to the preparation of a design, implementation and implementation for machining a detail is the process of preparing the production of the modernized element presented in the article. The process of re-designing the bolt lever used in the sewing machine head has been presented.

\section{Purpose of modernization}

The modernization of the numerically controlled sewing machine, used in the production of textile products, was aimed at eliminating the damage occurring during its operation [1].
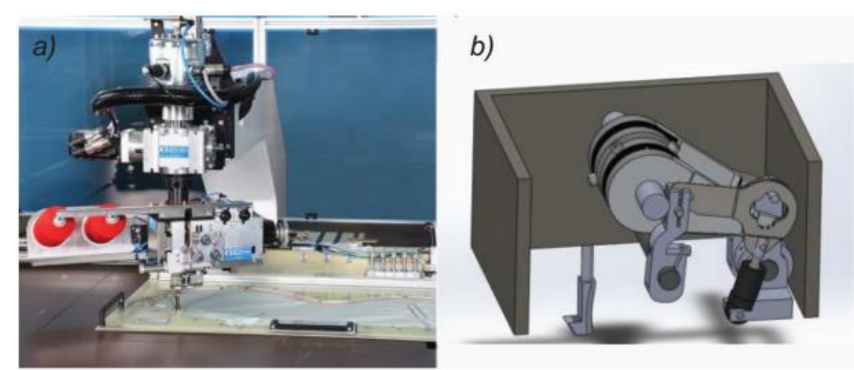

Fig. 1. Sewing machine during the sewing process (a) and the virtual model of the sewing head $(b)$

During the implementation of various types of sewing processes, it was found that the sewing head of the sewing machine is the most vulnerable and damaged sewing machine assembly. Accidental collisions may occur due to operator errors or material consumption leading to thread entanglement.

The rotating sewing head of the machine allows you to carry out the sewing process in any direction (fig. 1a). Changes in the sewing process direction are based on the NC program controlling the movements of both the sewing head and the tray on which the stitched material is laid.

The most heavily exposed element of damage caused by possible collision is the lock lever. Also during the implementation of typical production tasks, this element is most exposed to the occurrence of a sudden overload leading to the risk of its damage, as well as the processes of intensive wear caused by significant loads on the contact surface of the lever with other elements of the head. In connection with this, the actions were directed to the modernization of this particular element of the sewing machine [1]. 
The use of one of the CAD systems (SolidWorks) allows you to model the head during the sewing process (fig. 1b).

The starting point of activities to minimize the failure rate of the sewing machine was the analysis of the operation of the bolt lever and the loads affecting it. Its work is controlled by a solenoid actuating the pneumatic cylinder.

Extending or retracting the actuator activates or disengages the rolling motion of the presser foot. At the moment of sewing, the lever on the bolt is in the lower position (fig. 2a). When the machine returns from the sewing process after the sewing is completed, the cylinder is overdriven, lifting the lock lever up (fig. $2 b$ ).

Analyses carried out both on the virtual model and on real elements allowed to pre-determine the assumptions of modernization.
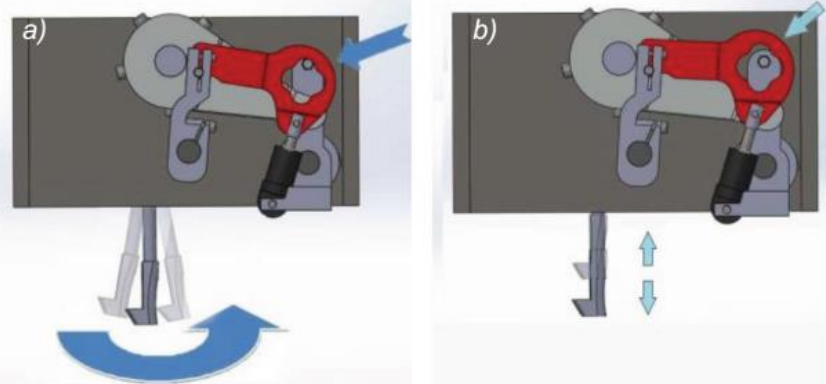

Fig. 2. Work of the presser foot with the deadbolt lever lowered (a) and with the raised bolt lever $(b)$

\section{Development of a project of a modernized shape of the lock lever}

The development of the initial concept of modernization of the bolt lever allowed for the transition to the computer stage of the construction record using the selected CAD system (SolidWorks). The redesigned lever is shown in fig. 3.

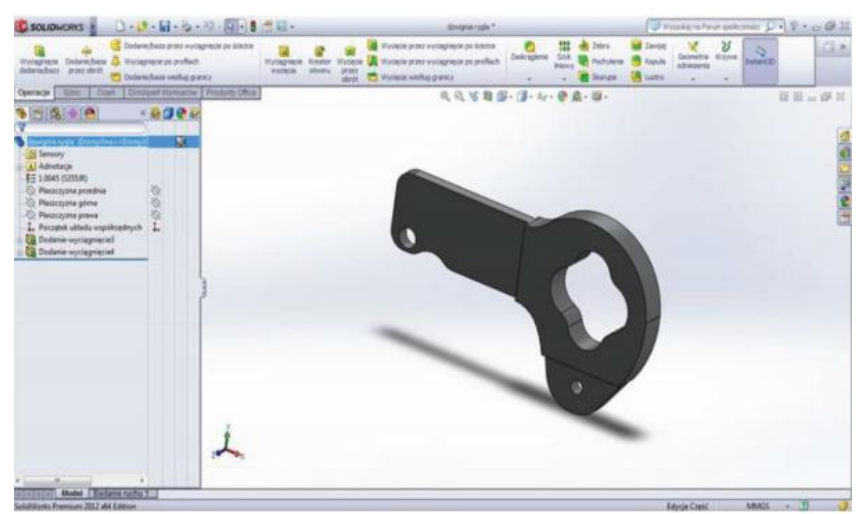

Fig. 3. Design of a modernized bolt lever

\section{Optimization of the structure in terms of strength}

Virtual and experimental analysis of the work of the sewing head allowed to estimate the loads and extortions affecting the modernized element. The SolidWorks program (SimulationXpress add-on) enables simulation of stresses and deformations of an element using the FEM method, so that it can perform the functional tasks placed before it in an optimal way.

Virtual tests of both levers in the original version as well as a number of variants of the correct shape of the parts were carried out. During the numerical simulations, boundary conditions were assumed corresponding to the characteristic lever positions during the correct operation of the device.
The boundary conditions characteristic for the moments of potential collisions and emergency stopping of the sewing head were also analyzed. This allowed the selection of the best variant of the proposed design changes for reasons of durability.

Simulation tests were carried out for loading forces up to $2000 \mathrm{~N}$, which corresponded to the predicted maximum forces that may occur during potential collisions. The distribution of reduced stresses and strains of the modified lever for this maximum loading force is shown in fig. 4.
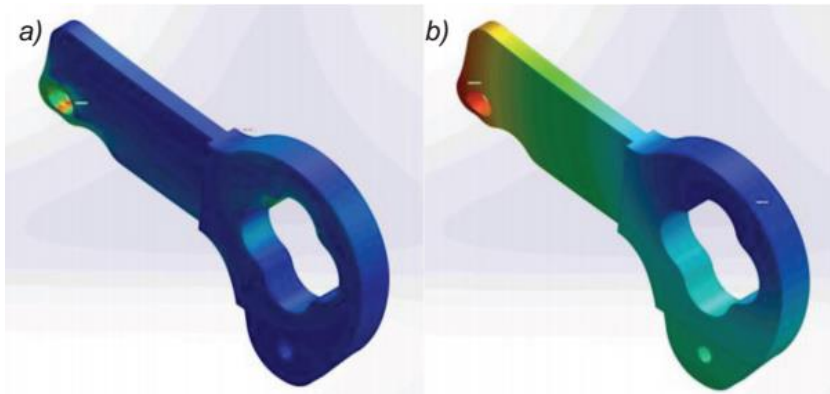

Fig. 4. Distribution of the reduced stresses (a) and deformations $(b)$ of the moderated lock lever

The simulation analysis allowed to state that during any collision at any point of the modernized structure, the yield point of the selected material was not exceeded. At the same time, during the stable operation of the machine, there was no excessive load on the redesigned element.

\section{Simulation of the operation of the redesigned sewing head solution}

The adoption of the final shape and dimensions of the revised anchor lever solution made it possible to check the action and correct the shapes of the other components of the sewing head (fig. 5).

The components of the head cooperating with the lever of the bolt (the eccentric and left eccentricity, pins, transport lever of the needle bar, the locking sleeve, etc.) were subject to verification and corrections.

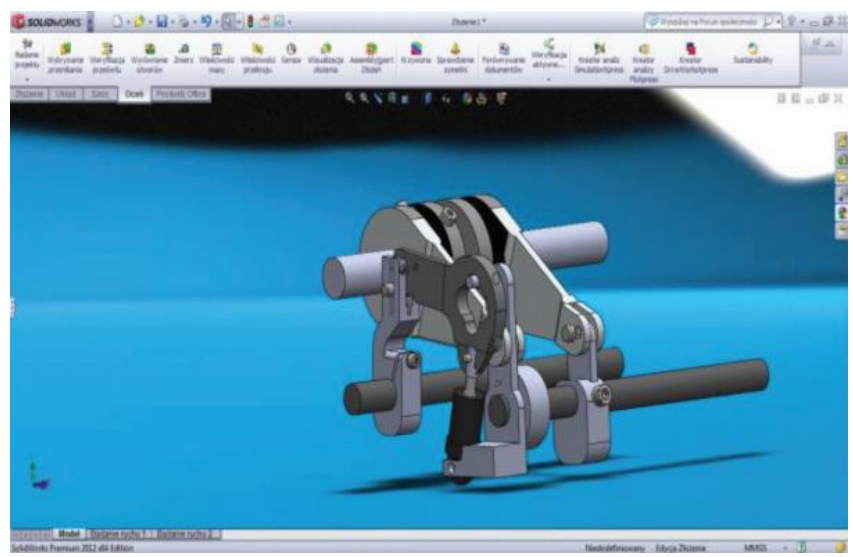

Fig. 5. Mechanism of the modernized sewing head

\section{Preparation of the process of making the bolt lever}

The technological process was developed with the aim of carrying out the treatment of the modernized lock lever performed for specific, individual needs.

The preparation of the technological process at the OSN was started by loading the three-dimensional model of the lever's lever into the CAM system (EdgeCAM) and defining the shape of the blank. The blank outline was created on the 
basis of the loaded lever shapes. A processing handle (vise) was used.

The next step in the program is the setting of the zero point in the corner of the blank and the choice of the machine tool along with the postprocessor. After starting the search for material features, the program automatically conducts inspection of planes, openings, pockets and stamps.

The machining plan included:

- first mounting: coarse flat region upper coarse, rough stamp perimeter, coarse open pouch 1 , coarse open pocket 2 , coarse rounding stamp, finishing punch perimeter, finishing punch circumferentially rounding, coarse pocket, finishing open pocket 1 , finishing open pocket 2 , finishing pocket, drilling points for drilling, drilling hole $\varnothing 6$, drilling hole $\varnothing 8$,

- second clamping: roughing flat region, roughing open pocket 1 , rough machining open pocket 2 , finishing open pocket 1 , finishing open pocket 2 .

For all machining operations planned in the machining process, it was necessary to define the technological parameters and select the appropriate machining tool from the available base. An exemplary process of selection of machining parameters for the finishing treatment of profiling is presented in fig. 6 . In the similar way, the procedures carried out in the second fixation shown in fig. 7 were carried out.

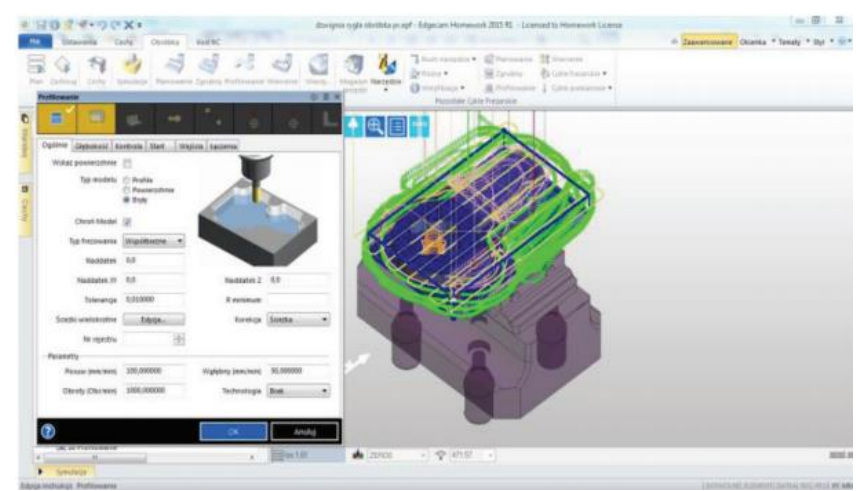

Fig. 6. Defining the finishing treatment of profiling

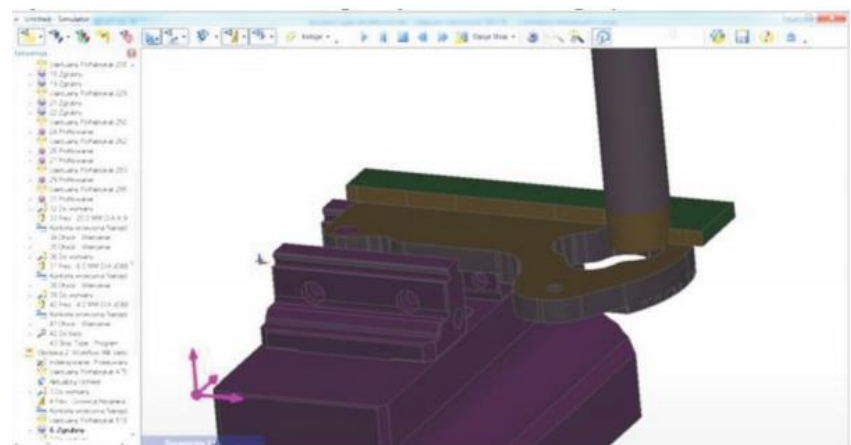

Fig. 7. Visualization of roughing surface treatment in the second clamping

The final stage of work with the CAD/CAM system was a virtual simulation of the machining process. $3 D$ simulation allows you to check the machining in terms of correctness of workmanship and check for possible collisions on the machine. An important and useful feature implemented by the EdgeCAM system is the verification of the accuracy of the performance, comparing the deviations between the "virtually" made in the simulator with the detail and the dimensions of the designed detail read from the CAD file (fig. 8).

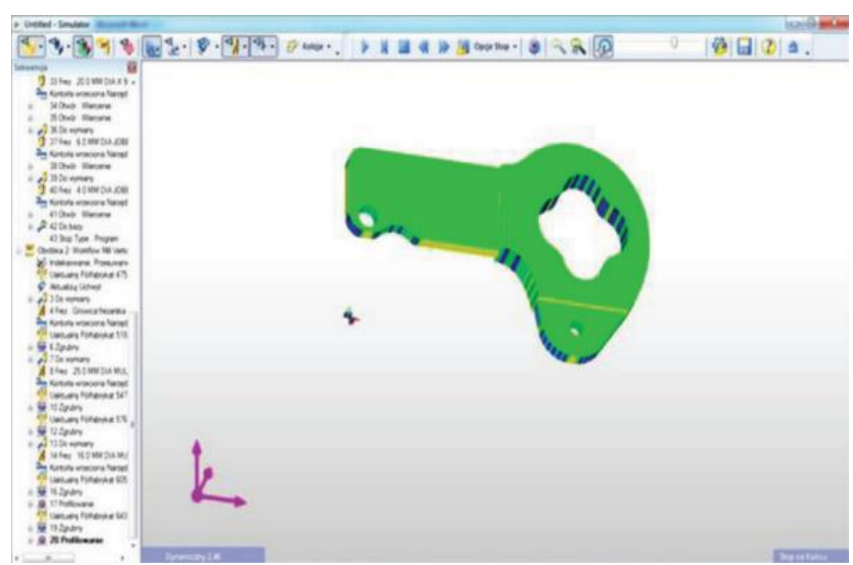

Fig. 8. Verification of the accuracy of workmanship

Verification of the correctness of the implementation of the prepared machining process and the elimination of possible errors made it possible to generate the code controlling the numerical machine tool and to prepare the technological documentation of the machining process.

\section{Conclusions}

An example of a comprehensive preparation of the production process is presented: from the concept, through the drawing, strength verification of the modified detail, verification of the correct operation of the modernized mechanism, development of the technology, until the final control program of the machine tool is obtained. The use of contemporary $\mathrm{CAD} / \mathrm{CAM} / \mathrm{CAE}$ systems available on the market not only significantly accelerates the process of designing and developing technology, but also significantly improves the quality of prepared production processes.

\section{REFERENCES}

1. Staniec P. Komputerowo wspomagane opracowanie technologii obróbki wyrobu na OSN". Praca dyplomowa inżynierska. Instytut Technologii Mechanicznych. Częstochowa: Politechnika Częstochowska, 2015.

2. Tagowski M., Zaborski A. „Przygotowanie produkcji wyrobów przy zastosowaniu systemów CAD i CAD/CAM". Mechanik. 88, 7 (2015): s. $568 / 849-856$ (CD).

3. Tagowski M., Zaborski A. „Przygotowanie produkcji wyrobów na OSN przy zastosowaniu systemów CAD/CAM". Mechanik. 89, 7 (2016): p. 846-847.

4. Tagowski M., Zaborski A. „Komputerowo wspomagane przygotowanie wykonania oprzyrządowania technologicznego przy wykorzystaniu systemów CAD/CAM". Mechanik. 90, 7 (2017): p. 578-580.

5. Zaborski A., Tubielewicz K. „Zastosowanie systemów CAD/CAM do komputerowo wspomaganego przygotowania produkcji". Mechanik. 77, 8-9 (2004): p. 588-591.

6. Zaborski A., Tubielewicz K. „Przygotowanie produkcji przy zastosowaniu systemów komputerowych". Biuletyn Wojskowej Akademii Technicznej. 56, 1 spec. (2007): p. 127-138.

Translation of scientific articles, their computer composition and publishing them on the website www.mechanik.media.pl by original articles in Polish is a task financed from the funds of the Ministry of Science and Higher Education designated for dissemination of science.

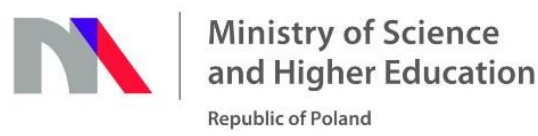

